\title{
Scutellaria Polysaccharide Mediates the Immunity and Antioxidant Capacity of the Giant Freshwater Prawn (Macrobrachium Rosenbergii)
}

\section{Lindan Sun}

Jiangsu University

\section{Feng Lin}

Zhejiang Institute of Freshwater Fisheries

\section{Yulei Zhang}

Guangdong Ocean University

\section{Zhendong Qin}

Zhongkai University of Agriculture and Engineering

\section{Fei Shi}

Zhongkai University of Agriculture and Engineering

\section{Youlu Su}

Zhongkai University of Agriculture and Engineering

\section{Chun Liu}

Zhongkai University of Agriculture and Engineering

\section{Lijuan Zhao}

Zhongkai University of Agriculture and Engineering

Jun Li

Lake Superior State University

Keping Chen

Jiangsu University

Li Lin ( $\square$ linli@zhku.edu.cn)

Zhongkai University of Agriculture and Engineering

\section{Research}

Keywords: Macrobrachium rosenbergii, Scutellaria polysaccharide, immunity capacity, antioxidant capacity

Posted Date: January 15th, 2021

DOI: https://doi.org/10.21203/rs.3.rs-146252/v1 
License: (c) (i) This work is licensed under a Creative Commons Attribution 4.0 International License. Read Full License 


\section{Scutellaria polysaccharide mediates the immunity and antioxidant}

capacity of the giant freshwater prawn (Macrobrachium rosenbergii)

Lindan Sun ${ }^{\mathrm{a}}$, Feng Lin ${ }^{\mathrm{e}}$, Yulei Zhang ${ }^{\mathrm{b}}$, Zhendong Qin ${ }^{\mathrm{c}}$, Fei Shi ${ }^{\mathrm{c}}$, Youlu Su${ }^{\mathrm{c}}$, Chun Liuc $^{c}$, Lijuan Zhao ${ }^{c}$, Jun Li ${ }^{\text {c, d }}$, Keping Chen ${ }^{a^{*}}$, Li Lin ${ }^{\text {c,d* }}$

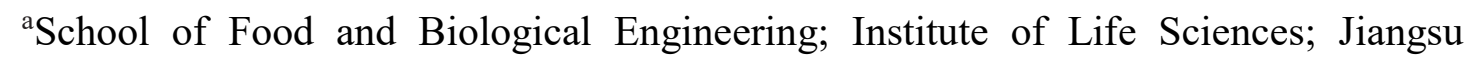
University, Zhenjiang 212013, China

${ }^{\mathrm{b}}$ Guangdong South China Sea Key Laboratory of Aquaculture for Aquatic Economic Animals, Guangdong Ocean University

${ }^{\mathrm{c}}$ Guangdong Provincial Water Environment and Aquatic Products Security Engineering Technology Research Center; Guangzhou Key Laboratory of Aquatic Animal Diseases and Waterfowl Breeding; College of Animal Sciences and Technology, Zhongkai University of Agriculture and Engineering, Guangzhou, Guangdong, 510225, China;

${ }^{\mathrm{d} S c h o o l ~ o f ~ B i o l o g i c a l ~ S c i e n c e s, ~ L a k e ~ S u p e r i o r ~ S t a t e ~ U n i v e r s i t y, ~ S a u l t ~ S t e . ~ M a r i e, ~ M I, ~}$ 49783, USA;

${ }^{\mathrm{e}}$ Key Laboratory of Healthy Freshwater Aquaculture, Ministry of Agriculture, Zhejiang Institute of Freshwater Fisheries, Huzhou 313001, China

\section{Correspondence:}

Prof. Dr. Li Lin, E-mail address: linli@,zhku.edu.cn; College of Animal Sciences and Technology, Zhongkai University of Agriculture and Engineering, Guangzhou, Guangdong, 510225, China; Prof. Dr. Keping Chen, E-mail address: 
21 kpchen@ujs.edu.cn; School of Food and Biological Engineering; Institute of Life 22 Sciences, Jiangsu University, Zhenjiang, Jiangsu, 212013, China.

23 


\section{Abstract}

Background: The giant freshwater prawn (Macrobrachium rosenbergii) is a commercially valuable freshwater crustacean species that is cultivated throughout the world. M. rosenbergii is frequently affected by a variety of diseases. Therefore, feed additive research is necessary to improve the immunity and survival rate of $M$. rosenbergii. Scutellaria polysaccharide (SPS) extracted from Scutellaria baicalensis (a Chinese medicinal herb) can enhance the antioxidant ability of organisms.

Methods: In this study, M. rosenbergii were fed with $50 \mathrm{mg} / \mathrm{kg}, 100 \mathrm{mg} / \mathrm{kg}$, and 150 $\mathrm{mg} / \mathrm{kg}$ of SPS. Following a four-week feeding trial, SPS had no positive effect on the growth of $M$. rosenbergii compared with the control group. Then, the immunity and antioxidant capacity of $M$. rosenbergii were tested by qRT-PCR and enzyme activities.

Results: The results showed that the expressions of prophenoloxidase (proPO) and toll receptor (Toll-R) mRNA showed no changes in hemocytes of $M$. rosenbergii. However, the expressions of heat shock protein 70 (HSP70) and nuclear factor $\kappa \mathrm{B}(\mathrm{NF}-\kappa \mathrm{B})$ mRNA were up-regulated during the first two weeks of culture and were downregulated in weeks 3 and 4. The mRNA expressions of HSP70, NF- $\kappa B$, and Toll-R (participating in the immune response) in heart, muscle, and hepatopancreas were decreased after four weeks of SPS feeding. This indicated that long-term feeding of SPS could regulate the immune responses of $M$. rosenbergii. The activity levels of antioxidant biomarkers, alkaline phosphatase (ACP), acid phosphatase (AKP), polyphenol oxidase (PPO), catalase (CAT), and superoxide dismutase (SOD), in 
45

46

47

48

49

50

51

52

53

54

55

56

57

58

59

60

61

62

63

64 61

hemocytes, heart, muscle, and hepatopancreas increased during the feeding time, indicating that the antioxidant capacity of $M$. rosenbergii was improved by SPS supplementation in the feed.

Conclusions: In summary, SPS was conducive to enhancing the antioxidant capacity of $M$. rosenbergii. These results provide a theoretical basis in supporting of SPS addition to the feed of M. rosenbergii.

Keywords: Macrobrachium rosenbergii; Scutellaria polysaccharide; immunity capacity; antioxidant capacity

(1)
5 56 57 58 59 60 62 3 64 


\section{Background}

The giant freshwater prawn (Macrobrachium rosenbergii) is a commercially valuable freshwater crustacean species, which is cultured all over the world. Numerous pathogens, such as the white spot syndrome virus (WSSV), Vibrio harveyi, and $V$. alginolyticus negatively impact the health of $M$. rosenbergii, thus threatening the $M$. rosenbergii aquaculture industry. The resistance of $M$. rosenbergii to external pathogens relies on humoral and cellular immunity [1]. Prophenoloxidase (proPO), a key enzyme in the melanization cascade, is the zymogen form of phenoloxidase (PO), which is involved in invertebrate immune reactions [2-4]. The antioxidant system can eliminate reactive oxygen species (ROS) and protect organisms from oxidative damage [5]. Therefore, enhancing the immunity and antioxidant capacity of $M$. rosenbergii is helpful to combat the damage caused by pathogens on the shrimp.

Recently, Chinese herbal medicines have been extensively investigated for their antiviral, antimicrobial, and anti-inflammatory effects $[6,7]$. Chinese herbal medicines are widely used in aquaculture because of their excellent efficacy (no drug resistance and residue, and few side-effects) [8]. In previous studies, various Chinese herbs synergistically improved the nonspecific immunity of numerous fish species, such as the common carp (Cyprinus carpio) [9], the tilapia (Oreochromis niloticus) [10], the Chinese prawn (Fenneropenaeus chinensis) [11], and the flounder (Paralichthys olivaceus) $[12,13]$.

Scutellaria polysaccharide (SPS) is extracted from the root of Scutellaria 
baicalensis, which is a traditional Chinese herb and widely prescribed to treat bacterial infections in humans [14]. A recent study showed that the stem and leaves (aerial parts) of $S$. baicalensis had extensive antibacterial effects on Aeromonas hydrophila, Edwardsiella tarda, V. alginolyticus, and V. harveyi [6]. The root of S. baicalensis exerted the strongest antioxidant activity compared with leaves, stems, and flowers [15]. S. baicalensis roots work as a strong free radical scavenger with high antioxidant capacity [16-20]. Therefore, it can protect cells from oxidative stress [21], immune hepatitis [22], and allergic dermatitis [23, 24]. SPS has excellent antioxidant effects on organisms [25-28]. SPS has been widely added to animal feed to prevent cardiovascular diseases in pigs [29] and improve the immune capacity of chickens [30]. However, the antioxidant and immunomodulatory effects of SPS on $M$. rosenbergii still remain unclear.

In this study, different concentrations of SPS were used as feed supplement for $M$. rosenbergii. Furthermore, the levels of immune and antioxidant indexes were traced. The results provide insight into the immunoregulatory and antioxidant functions of SPS in M. rosenbergii.

\section{Materials and methods}

\section{Experimental materials}

M. rosenbergii was collected from the Zhejiang Freshwater Fisheries Research Institute (Huzhou, Zhejiang, China). SPS was obtained from Xi'an XIAOCAO 
107

108

109

110

111

112

113

114

115

116

117

Botanical Development Co., Ltd., China. $50 \mathrm{mg} / \mathrm{kg}, 100 \mathrm{mg} / \mathrm{kg}$, and $150 \mathrm{mg} / \mathrm{kg}$ of SPS (85\%) were added to the basic feed (Guangdong Haid Group Co., Ltd., China), containing high-quality fish meal, soybean meal, peanut bran, shrimp shell powder, flour, yeast powder, multimineral and multi-dimensional food inducers. It was composed of $40 \%$ crude protein, $4 \%$ crude fat, $15 \%$ crude ash, $12 \%$ moisture, $5 \%$ crude fiber, $4 \%$ calcium, and $1 \%$ phosphorus.

\section{Experimental design}

A total of 720 prawns (body weight of $15.84 \pm 2.87 \mathrm{~g}$ ) were randomly divided into four groups, namely the control, $50 \mathrm{mg} / \mathrm{kg}, 100 \mathrm{mg} / \mathrm{kg}$, and $150 \mathrm{mg} / \mathrm{kg}$ groups. Each group used three replicates with 60 tails per replicate. The experiment was continued for one month, and samples were drawn every other week. The growth performance, as well as the antioxidant and immunity capacity of $M$. rosenbergii were determined.

\section{Sample collection}

The prawns were anesthetized with tricaine methanesulfonate (MS-222, A5040, Sigma, USA) and sampled every other week. From each group, the prawns of 10 trails were weighed and counted. The prawns were anesthetized, and their blood was drawn into sterile centrifuge tubes. The heart, muscle, and hepatopancreas were dissected and placed in sterile centrifuge tubes. All samples were snap-frozen in liquid nitrogen and temporarily stored at $-80{ }^{\circ} \mathrm{C}$ for further analysis.

\section{Expression analysis of immune factors by quantitative real-time polymerase chain reaction (qRT-PCR)}

The mRNA levels of proPO, heat shock protein 70 (HSP70), toll receptor (Toll- 
$\mathrm{R}$ ), and nuclear factor $\kappa \mathrm{B}(\mathrm{NF}-\mathrm{\kappa} \mathrm{B})$ were determined by qRT-PCR. Total RNA was extracted from the samples by Trizol (Invitrogen, Waltham, MA, USA) according to the manufacturer's instructions. The RNA was reverse-transcribed into complementary DNA (cDNA) (TaKaRa, Japan) and stored at $-20{ }^{\circ} \mathrm{C}$ for qRT-PCR. The primer sequences of proPO, HSP70, Toll-R, and NF-kB genes were designed using online Primer 3 (NCBI/Primer-BLAST) (http://www.ncbi.nlm.nih.gov/tools/primer-blast/) (Table 1). $\beta$-actin was used as internal control. Each sample was measured in triplicate according to the following procedure: incubation at $95{ }^{\circ} \mathrm{C}$ for $30 \mathrm{~s}$, followed by 40 cycles of $95^{\circ} \mathrm{C}$ for $5 \mathrm{~s}, 55^{\circ} \mathrm{C}$ for $20 \mathrm{~s}, 72{ }^{\circ} \mathrm{C}$ for $20 \mathrm{~s}$, and $4{ }^{\circ} \mathrm{C}$ for $5 \mathrm{~min}$. A meltingcurve analysis was performed to determine the target specificity. The relative expression ratio of the target genes versus the $\beta$-actin gene was calculated using the $2^{-}$ ${ }^{\Delta \Delta C \mathrm{CT}}$ method, and all data were given in terms of relative mRNA expression.

\section{Determination of antioxidant enzyme activities}

The activity levels of alkaline phosphatase (ACP), acid phosphatase (AKP), polyphenol oxidase (PPO), catalase (CAT), and superoxide dismutase (SOD) were determined with the respective enzyme activity assay kits (Nanjing Jiancheng Bioengineering Institute, China). The protein concentration in each sample was determined by protein assay kit (A045-4, Nanjing Jiancheng Bioengineering Institute, China). The article numbers of the kits are A060 (ACP), a059-2 (AKP), a136-1-1 (PPO), A007-1 (CAT), and a001-3 (SOD). The tissues were collected, and sample diluent was added as substrate. After incubation for $30 \mathrm{~min}$, the enzyme activities were measured using a microplate reader at absorbances of $520 \mathrm{~nm}$ (ACP), $520 \mathrm{~nm}$ (AKP), $420 \mathrm{~nm}$ 
151

152

153

154

155

156

157

158

159

160

161

162

163

164

165

166

167

168

169

170

(PPO), $450 \mathrm{~nm}$ (SOD), and $405 \mathrm{~nm}$ (CAT). To compare the parameters of enzyme activity, the control group was homogenized over the four weeks. The enzyme activity of $50 \mathrm{mg} / \mathrm{kg}, 100 \mathrm{mg} / \mathrm{kg}$, and $150 \mathrm{mg} / \mathrm{kg}$ groups was compared with those of the control group. The activity of the control group was one every week. The relative value was used to evaluate the antioxidant indicators and identify changes.

\section{Results}

\section{Effect of SPS on the growth of M. rosenbergii}

The body weights of control and experimental groups is shown in Fig. 1. The body weights of control and experimental groups increased from $16 \mathrm{~g} / 10$ prawn in the first week to $55 \mathrm{~g} / 10$ prawn in the fourth week. The body weight of the experimental groups significantly decreased compared with the control group, indicating that SPS had no growth-promoting effect. The survival rates of prawns in control, $50 \mathrm{mg} / \mathrm{kg}, 100 \mathrm{mg} / \mathrm{kg}$, and $150 \mathrm{mg} / \mathrm{kg}$ SPS groups exceeded 93\%. However, there was no significant difference between these groups, indicating that SPS did not affect the survival rates of prawns.

\section{Effect of SPS on the immunity capacity of M. rosenbergii hemocytes}

In invertebrates, the inactive proPO is converted into the active prophenoloxidase (PO) to participate in the immune response. HSP70 is a basic indicator for stress responses in organisms. NF- $\kappa \mathrm{B}$ regulates the immune and inflammatory responses in 
171 prawn tissues. Toll-R participates in nonspecific immunity and bridges nonspecific and

172 specific immunity. After culturing prawns for four weeks, the mRNA levels of proPO

173 and Toll-R showed no change in the experimental groups, while Toll-R was up-

174 regulated in the second week of culture. HSP70 and NF- $\mathrm{BB}$ mRNA expressions were

175 up-regulated in the second week of culture and down-regulated in the third and fourth 176 weeks of culture (Fig. 2).

177 Effect of SPS on the immunity capacity of M. rosenbergii tissues

During the breeding period, the HSP70 level followed a decreasing trend (Fig. 3A).

179 After one week of culturing prawns the expression of HSP70 was slightly decreased in the $50 \mathrm{mg} / \mathrm{kg}$ and $100 \mathrm{mg} / \mathrm{kg}$ groups. Furthermore, decreases of HSP70 were observed 181 in the $100 \mathrm{mg} / \mathrm{kg}$ and $150 \mathrm{mg} / \mathrm{kg}$ groups after culturing for two weeks, especially in the muscle tissue and the hepatopancreas.

As shown in Fig. 3B, the expression level of NF- $\mathrm{BB}$ was increased in the first week and significantly decreased in the fourth week. In the $50 \mathrm{mg} / \mathrm{kg}$ and $100 \mathrm{mg} / \mathrm{kg}$ groups in the third feeding week, the mRNA expression levels had increased in muscle tissue but decreased in the liver and hepatopancreas. decreased in the hepatopancreas. 


\section{Effect of SPS on antioxidant capacity of M. rosenbergii hemocytes}

192

193

194

195

196

197

ACP and AKP are the most important indexes of antioxidant enzymes in crustaceans. PPO is another important index of antioxidant enzyme in crustaceans. Both SOD and CAT are members of the antioxidant enzyme defense system, and scavenge free oxygen radicals in the body. SOD can protect cells from oxidative damage, and CAT activity reflects the anti-lipid peroxidation ability of the body. The activities of ACP, AKP, and PPO increased in hemocytes over the entire feeding time. The CAT activity increased in 50 and $100 \mathrm{mg} / \mathrm{kg}$ groups, but decreased in the $150 \mathrm{mg} / \mathrm{kg}$ group (Fig. 4).

\section{Effect of SPS on antioxidant capacity of M. rosenbergii tissues}

The ACP levels exhibited a complex trend in heart, muscle, and hepatopancreas (Fig. 5A). The level of ACP expression in the heart increased in the second and third weeks of culture. The enzyme activity significantly decreased in the hepatopancreas in the third week of culture and remained stable in the fourth week.

After one week of culture, the activity of AKP increased in both heart and muscle tissues (Fig. 5B). After two weeks of culture, the activity of the AKP enzyme increased significantly in muscle tissue. After four weeks of culture, enzyme activity decreased in heart and muscle tissue and increased in the hepatopancreas. These results suggest that muscle AKP might be sensitive to the feeding duration of SPS.

After two weeks of culture, the heart and muscle PPO levels decreased, and the 
hepatopancreas PPO level increased (Fig. 5C). Over three weeks of culture, PPO levels increased in the heart, muscle, and hepatopancreas. After four weeks of culture, PPO decreased, which indicates that polysaccharides can increase the activity of PPO at the appropriate time.

The SOD levels increased in the heart, muscle, and hepatopancreas over the four weeks of cultivation (Fig. 5D). However, a significant increase in the SOD level was found in the hepatopancreas after two weeks of culture, indicating that the hepatopancreas is the most sensitive organ to SPS.

As shown in Fig. 5E, the CAT levels increased significantly in heart, muscle, and hepatopancreas tissues after three weeks of culture. In the fourth week, the CAT activity level was higher than levels in the third week of culture. The results showed that longterm feeding of SPS enhanced CAT activity and overall antioxidant capacity.

\section{Discussion}

Nutrition and immunity are two crucial factors that affect the health of organisms. The different nutrient levels affect the immune function of the body, whereas the immune system influences the nutrient requirements of the organism [31]. Chinese herbal medicine can enhance the immunity of the body. Chinese herbal medicine enhanced the humoral immunity and cellular immune function of immunosuppressed mice [32]. Addition of a Chinese traditional herbal complex to diets had beneficial effects on the immunity of pigs [33]. Traditional Chinese medicine could successfully 
stimulate the immunity of aquatic animals and improve the nonspecific immune function [9]. S. baicalensis was reported to stimulate the growth and antimicrobial activities of flounder (P. olivaceus) [34]. SPS increases the antioxidant activity of the liver [35], offers resistance to viruses [36], and has immune functions [37] in both humans and animals. SPS significantly inhibited the infectivity of Newcastle disease virus in chicken embryo fibroblasts and showed antiviral activity [38]. SPS could inhibit virus replication at the cellular level as indicated by Trypan blue exclusive assay, immunofluorescence assay, and PCR methods [36]. SPS could inhibit NF-kB signaling and NLRP3 inflammasome activation, thus decreasing the disease activity index and myeloperoxidase activity [28]. SPS could improve the nonspecific and specific immune abilities of mice by increasing the IgG, IgM, and IgA levels in serum [39]. However, the influence of SPS on the immune and antioxidant abilities of M. rosenbergii has not been investigated to date. In this study, the effects of SPS on the immunity and antioxidant capacity of M. rosenbergii were analyzed.

The immune response of prawns is relatively primitive. The prawn mainly relies on innate immunity to resist pathogenic microorganisms. Therefore, the research on the immune mechanism of prawn mainly focuses on the antioxidant enzyme system, Toll receptor, HSP70, and other immune-related factors [40]. In crustaceans, hemocytes play a vital role in both cellular and humoral immunity. Immune indicators were tested in hemocytes. The proPO activation system activates PO activity, which is involved in the immune response of invertebrates against pathogens [41]. In this study, the mRNA expressions of proPO showed no change in hemocytes. The results demonstrated that 
the effects of proPO on the immunocompetence of $M$. rosenbergii were not significant with prolonged feeding time. The PO activity of the Chinese prawn was high $4 \mathrm{~h}$ after injection with peptidoglycan [42] and $48 \mathrm{~h}$ after dietary administration of fungal polysaccharides [43]. Moreover, long-term feeding of immune polysaccharides can affect the immune function both positively and negatively [44, 45]. HSP70 is a member of the heat shock protein family, which is induced in stressed cells of organisms. Heat shock proteins are well-known agents that protect organisms and cells, and the relative expression of these proteins determines the anti-stress ability of organisms [46]. In this study, the expression of HSP70 significantly increased in hemocytes after culturing for two weeks and decreased after culturing for three weeks in all groups. In tissues, the expression of HSP70 significantly decreased in the $100 \mathrm{mg} / \mathrm{kg}$ and $150 \mathrm{mg} / \mathrm{kg}$ groups after culturing for two weeks. This indicates that the appropriate concentration and feeding time of SPS could improve the health of M. rosenbergii. Chinese herbal medicine is a bidirectional immunomodulator [47], and can promote low immune function and inhibit hyperfunction. NF- $\mathrm{BB}$ and the Toll-R induce a range of immune responses in crustaceans $[48,49]$. NF- $\kappa \mathrm{B}$ is involved in the development of various inflammation-related diseases, and is key in modulating the immune and inflammatory responses by controlling the expression of inflammatory cytokines $[28,50]$. In this study, the relative expression level of NF- $\mathrm{BB}$ significantly decreased in the fourth week of culture in hemocytes, heart, muscle, and hepatopancreas, suggesting that long-term SPS feeding could regulate the immunity of M. rosenbergii. S. baicalensis has been reported to reduce inflammatory responses by inhibiting NF- $\kappa \mathrm{B}$ and MAPK pathways 
[51], suggesting that the roots of $S$. baicalensis can inhibit NF- $\mathrm{BB}$ and enhance immunity. Furthermore, Toll-R expression level decreased in all tissues and feeding stages, suggesting that SPS can indirectly regulate the expression of the Toll-R gene

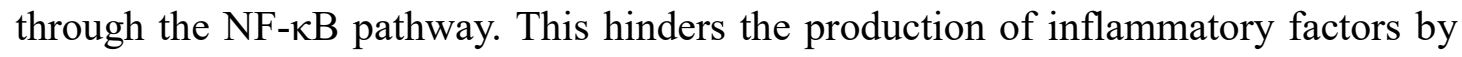
the innate immune system, thus improving the phagocytic ability and enhancing the killing ability of natural immune cells. The immune capacity of shrimp can be improved by immune stimulation and can be maintained for a certain period (several days to several months); however, the mechanism of SPS on M. rosenbergii should be further studied.

The antioxidant capacity can also reflect the immune capacity and health status. ACP, AKP, and PPO play important roles in the immune system of shrimp or prawn. Phosphatase can catalyze the hydrolysis of various phosphorous compounds. According to their optimal $\mathrm{pH}$ characteristics, phosphorous compounds can be divided into AKP and ACP. In this study, after feeding SPS at different concentrations, ACP and AKP enzyme activities increased in hemocytes over the whole feeding time. They also increased in heart and muscle tissues after the first feeding week, but decreased in the fourth feeding week. These results indicate that long-term feeding of SPS did not significantly enhance the activity of ACP and AKP. It has been demonstrated that longterm feeding of polysaccharides may fail to stimulate immune and antioxidant functions, or even decrease these [44]. Short term administration of SPS can promote ACP and AKP activities, which may stimulate the transfer and metabolism of ACP phosphate groups, and may provide more inorganic phosphoric acid for ADP phosphorylation to 
improve immunity and antioxidant capacity. PPO can recognize the invasion of foreign bodies and regulate the immune and antioxidant functions. Therefore, the activities of $\mathrm{ACP}$ and PPO enzymes reflect the immune function of prawn. Activated PPO can stimulate the synthesis of quinones in organisms, which spontaneously produce melanin. Melanin helps to protect from the invasion of foreign pathogens [52, 53]. It has been reported that in vivo and in vitro stimulation of the giant tiger prawn (Penaeus monodon) with yeast glucan significantly enhanced the PPO activity of hemolymph tissue [54]. The results of the present study showed that the PPO level increased in hemocytes, heart, muscle, and hepatopancreas in the third week of culture, indicating that polysaccharides can increase the PPO activity.

SOD and CAT are representative indexes of the antioxidant function $[55,56]$. SOD and CAT are important immune-related factors in the immune system of the body, which can reflect the body's nonspecific immune function [57]. In this study, SPS significantly increased the SOD and CAT activities in $50 \mathrm{mg} / \mathrm{kg}$ and $100 \mathrm{mg} / \mathrm{kg}$ groups in hemocytes, heart, muscle, and hepatopancreas. Another study found that SOD was strongly expressed in the heart of white-leg shrimp (Penaeus vannamei), stimulated by ROS after one week of culture [58]. S. baicalensis decreased the ROS level and maintained the equilibrium of ROS through biosynthesis [59]. S. baicalensis Georgi flower extract (SFE) could significantly reduce oxidative damage of aging rats by increasing their SOD level in the serum [60]. These results indicate that both short- and long-term administration of SPS benefits the antioxidant capacity of M. rosenbergii. 


\section{Conclusion}

321

322

323

324

325

326

327

328

329

330

331

332

333

334

The possible mechanism through which SPS regulates the immunity and antioxidant capacity of $M$. rosenbergii has been identified (Fig. 6). In summary, the SPS supplementation in feed regulated the mRNA of proPO, NF- $\kappa B$, HSP70, and Toll-R in M. rosenbergii. The activities of antioxidant-related enzymes (ACP, AKP, PPO, SOD, and CAT) increased. However, different tissues and their immune indexes had different sensitivities to SPS. The experimental data showed that long-term feeding of SPS could improve the antioxidant capacity of $M$. rosenbergii, which provides data for the preparation of compound Chinese herbal medicine.

\section{Ethics approval and consent to participate}

All experimental procedures were performed in accordance with the Guide for the Care and Use of Laboratory

Animals published by the US National Institutes of Health (NIH publication no.85-23 revised 1996).

Consent for publication

Not applicable.

Availability of data and materials

The datasets used and/or analyzed during the current study are available from the authors on reasonable request.

Competing interests

The authors have no conflicts of interest to declare.

\section{Funding}

This work was jointly supported by funds from the China Postdoctoral Science Foundation (2018M642185), the 


\section{Authors' contributions}

Lindan Sun, Feng Lin, Keping Chen and Li Lin designed the study. Lindan Sun and Feng Lin conducted the manuscript.

\section{Acknowledgments}

\section{References}


mollusca. Oceanologia et Limnologia Sinica. 1998.

362

[2] Xu HS, Xu BJ. Progress on the researches of cellular and humoral immunity of crustacean. Journal of Dalian Fisheries University. 2001.

[3] Cerenius L, Lee BL, Kennet S. The proPO-system: pros and cons for its role in invertebrate immunity. Trends Immunol. 2008; 29(6): 0-271.

[4] Sritunyalucksana K, Soderhall K. The proPO and clotting system in crustaceans. Aquaculture, 2000; 191(1-3): 53-69.

[5] Griboff J, Morales D, Bertrand L, Bonansea RI, Monferran MV, Asis R. Oxidative stress response induced by atrazine in palaemonetes argentinus: the protective effect of vitamin $\mathrm{E}$. Ecotox. Environ. Safe. 2014; 108(10): 1-8.

[6] Xia YT, Chan GKL, Wang HY, Dong TTX, Duan R, Hu WH, Qin QW, Wang WX, Tsim KWK. The antibacterial effects of aerial parts of Scutellaria baicalensis: Potential application as an additive in aquaculture feedings. 2020; Aquaculture, 526.

[7] Wang ZL, Wang S, Kuang Y, Hu ZM, Qiao X, Ye M. A comprehensive review on phytochemistry, pharmacology, and flavonoid biosynthesis of Scutellaria baicalensis. Pharm. Biol. 2018; 56 (1): $465-486$

[8] Pan SY, Chen SB, Dong HG, Yu ZL, Dong JC, Long ZX, Fong WF, Han YF, Ko KM. 2011. New perspectives on Chinese herbal medicine (Zhong-Yao) research and development. Evidence-Based Complement Alternative Med. 2011.

[9] Zhaona M, Yuchun C, Min L. Effect of Chinese herbal compounds on nonspecific immunity of Cyprinus carpio var.specularis Juvenile fish. Journal of Northeast Agricultural University, 2011; 42(3): 54-59. 
383

384

[10] Wu YR, Gong QF, Fang H. Effect of Sophora flavescens on nonspecific immune response of tilapia (GIFT Oreochromis niloticus) and disease resistance against Streptococcus agalactiae. Fish Shellfish Immun. 2013; 34(1): 220-227.

[11] Wang XQ, Ye JS, He ZZ, Shen MA, Yan BL. Effects of Salinity and Herbal Medicine Eupatorium lindleyanum on Growth in Juvenile Chinese Shrimp Fenneropenaeus chinensis. Fisheries Sci. 2008.

[12] Harikrishnan R, Heo J, Balasundaram C, Kim MC, Kim JS, Han YJ. Effect of Punica granatum solvent extracts on immune system and disease resistance in Paralichthys olivaceus against lymphocystis disease virus (LDV). Fish Shellfish Immun. 2010; 29: 668-673.

[13] Harikrishnan R, Kim JS, Kim MC, Balasundaram C, Heo MS. Prunella vulgaris enhances the nonspecific immune response and disease resistance of Paralichthys olivaceus against Uronema marinum. Aquaculture, 2011; 318: 61-66.

[14] Zhao T, Tang H, Xie L, Zhang Y, Li X. Scutellaria baicalensis Georgi (Lamiaceae): a review of its traditional uses, botany, phytochemistry, pharmacology and toxicology: A review of Scutellaria baicalensis Georgi. J Pharm. Pharma. 2019.

[15] Seo ON, Kim GS, Kim YH. Determination of polyphenol components of Korean Scutellaria baicalensis Georgi using liquid chromatography-tandem mass spectrometry: Contribution to overall antioxidant activity. J. Funct. Foods, 2013; 5(4): 1741-1750.

[16] Gao D, Sakurai K, Katoh M, Chen J, Ogiso T. Inhibition of microsomal lipid peroxidation by baicalein: A possible formation of an iron-baicalein complex. Biochem. Mol. Biol. Int. 1996; 39(2): $215-225$.

[17] Gao Z, Huang K, Yang X, Xu H. Free radical scavenging and antioxidant activities of 
flavonoids extracted from the radix of Scutellaria baicalensis Georgi. BBA-Gen. Subjects, 1999; $1472(3): 643-650$.

[18] Shieh DE, Liu LT, Lin CC. Antioxidant and free radical scavenging effects of baicalein, baicalin and wogonin. Anticancer Res. 2000; 20(5A): 2861.

[19] Chan E, Wong CYK, Wan CW, Kwok CY, Wu JH, Ng KM, So CH, Au ALS, Poon CCW, Seto SW, Kwan YW, Yu PHF, Chan SW. Evaluation of Antioxidant Capacity of Root of Scutellaria baicalensis Georgi, in Comparison with Roots of Polygonum multiflorum Thunb and Panax ginseng CA Meyer. Am. J. Chin. Med. 2010; 38(4): 815-827.

[20] Peng Y, Guo CS, Li PX, Fu ZZ, Gao LM. Immune and Antioxidant Functions of Ethanol Extracts of Scutellaria baicalensis Georgi in Mice Bearing U14 Cervical Cancers. Asian Pac. J. Cancer P. 2014; 15(10): 4129-4133.

[21] Shao ZH, Li CQ, Hoek TLV, Becker LB, Schumacker PT, Wu JA. Extract from Scutellaria baicalensis Georgi Attenuates Oxidant Stress in Cardiomyocytes. J. Mol. Cell. Cardiol. 1999; 31(10): 0-1895.

[22] Zhang Y, Shan L, Hua YP, Wang D, Zeng HW, Liu RH, Zhang WD, Hu ZL. Baicalein selectively in duces apoptosis in activated lymphocytes and ameliorates con canavalin ainduced hepatitis in mice. Plos One, 2013; 8 (7): e69592.

[23] Yun MY, Yang JH, Kim DK, Cheong KJ, Song HH, Kim DH, Cheong KJ, Kim YI, Shin SC. Therapeutic effects of Baucalein on atopic dermatitislike skin lesions of NC/Nga mice induced by dermatophagoides pteronyssinus. Int. Immunopharmacol, 2010; 10(9): 1142-1148.

[24] Hee SS, Min JB, Dae WC, Hwa DS. Skullcap (Scutellaria baicalensis) extract and its active compound, wogonin, inhibit ovalbumininduced Th2-Mediated response. Molecules, 2014; 
[25] Chen RZ, Liu ZQ, Zhao JM, Chen RP, Meng FL, Zhang M, Ge WC. Antioxidant and immunobiological activity of water-soluble polysaccharide fractions purified from Acanthopanax senticosu. Food Chem. 2011; 127(2): 434-440.

431

[26] Zhou XL, Choi PS, Yang JM, Penelope MYO, Hoi PM, Lee SMY, Leung GPH, Ngai SM, Kong SK, Ho HP, Wong MYM, Chan SW, Yeung JH, Kwan YW. Chemical and pharmacological evaluations on the extract of Scutellaria baicalensis Georgi (huang-qin) prepared by various extraction methods. Springerplus, 2016; 5(1): 1438.

[27] Liau PR, Wu MS, Lee CK. Inhibitory effects of Scutellaria baicalensis root extract on linoleic acid hydroperoxide-induced lung mitochondrial lipid peroxidation and antioxidant activities. Molecules, 2019; 24(11): 1-15.

[28] Cui L, Wang W, Luo Y, Ning Q, Xia Z, Chen J. Polysaccharide from Scutellaria baicalensis

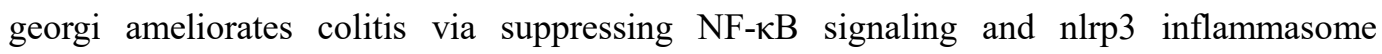
activation. Int. J. Biol. Macromol. 2019; 132: 393-405.

[29] Liu CQ, Huang Y. Chinese herbal medicine on cardiovascular diseases and the mechanisms of action. Front. Pharmacol. 2016; 7 (469).

[30] Króliczewska B, Graczyk S, Króliczewski J, Pliszczak-Król A, Miśtaand D, Zawadzki W. Investigation of the immune effects of Scutellaria baicalensis on blood leukocytes and selected organs of the chicken's lymphatic system. J. Anim. Sci. Biotechnol. 2017; 8 (22).

[31] Sturve J, Almroth BC, Förlin L. Oxidative stress in rainbow trout (Oncorhynchus mykiss) exposed to sewage treatment plant effluent. Ecotox. Environ. Safe. 2008; 70(3): 446-452. 
mice. Afr. J. Tradit. Complem. 2012; 9(4): 548-552.

[33] Yeh HS, Weng BC, Lien TF. Effects of chinese traditional herbal medicine complex supplementation on the growth performance, immunity and serum traits of pigs. Anim. Sci. J. 2011; 82(6): 747-752.

[34] Cho SH, Jeon GH, Kim HS, Kim DS, Kim C. Effects of Dietary Scutellaria baicalensis extraction growth, feed utilization and challenge test of olive flounder (Paralichthys olivaceus). Asian Austral. J. Anim. 2013; 26(1): 90-96.

[35] Zhou SW, Xu CF. Immunopharmacological action of polysaccharides. Chin. J. Bio. Pharm. $1994 ; 15: 141-142$.

[36] Zhang DG, Kwang J, Pan SL. Antiviral effect of polysaccharide from Scutellaria baicalensis Georgi on porcine respiratory and reproductive syndrome virus. Lishizhen Med. Mater. Med. Res. 2005; 16: 3-4

[37] Liang Y, Jiang N, He WJ, Ren CC, Wang DL, Zheng WF. Effects of Astragalus polysaccharide on growth performance and immune function of broilers. Chin. J. Anim. Nutr. 2010; 22: 10311036.

[38] Zhao XN, Liu JZ. Scutellaria polysaccharide inhibits the infectivity of Newcastle disease virus to chicken embryo fibroblast. J. Sci. Food Agr. 2013; 94: 779-784.

[39] Liang Y, Jin D, Li D. Immunoregulatory activity of polysaccharides from Scutellaria baicalensis Georgi. J. Chin. I. Food. Technol. 2017; 17: 23-27.

[40] Huang XX, Luo CX, Guo TF, Hua XM, Wen W, Zhou HQ. Toll receptor in prawn and its application in nutrition-immunity assessing on prawn. Journal of Fisheries of China, 2012; 36(6): 930-936. 
471 [41] Yannick M, Paul SH. Immune defence in bumble-bee offspring. Nature, 2001; 414(6863): 506472506.

473 [42] Meng FL, Zhang YZ, Kong J, Ma GR. The research review of prophenoloxidase activating system in crustacean. Oceanologia Et Limnologia Sinica, 1999; 30: 110-116.

475 [43] Chang MX, Chen X. Effects of two kinds of polysaccharide on the phenoloxidase activity in macrobrachium nipponense. Acta Hydrobiologica Sinica, 2003; 27(3): 269-272.

477 [44] Yoshida T, Kruger R, Inglis V. Augmentation of nonspecific protection in African catfish, Clarias gariepinus (Burchell), by the long-term oral administration of immunostimulants. J Fish Dis. 1995; 18: 195-198.

[46] Basu N, Todgham AE, Ackerman PA, Bibeau MR, Nakano K, Schulte PM. Heat shock protein

[45] Chang CF, Chen HY, Su MS. Immunomodulation by dietary $\beta$-1, 3-glucan in the brooders of

[47] ZhangYW, Zheng JW, Li WH, Xiao LC. Effects of Chinese Herbal Medicines on Growth and Nonspecific Immunity in Yellow Catfish Pelteobagrus fulvidraco. Fisheries Sci. 2010.

[48] Gay NJ, Keith FJ. Drosophila Toll and IL-1 receptor. Nature, 1991; 351(6325): 355-356.

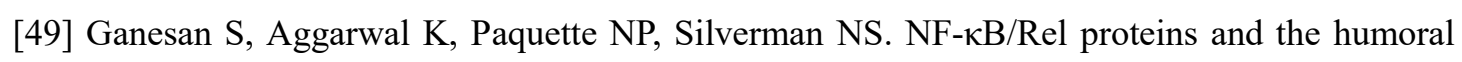
immune responses of Drosophila melanogaster. Curr. Top. Microbiol. 2011; 349(5): 25-60.

[50] Siddique I, Khan I. Mechanism of regulation of Na-H exchanger in inflammatory bowel disease: role of TLR-4 signaling mechanism. Dig. Dis. Sci. 2011; 56 (6): 1656-1662.

[51] Hong GE, Kim JA, Nagappan A. Flavonoids Identified from Korean Scutellaria baicalensis Georgi Inhibit Inflammatory Signaling by Suppressing Activation of NF- $\mathrm{B}$ and MAPK in 
[52] Söderhäll K, Cerenius L. Role of the prophenoloxidase activating system in invertebrate immunity. Curr. Opin. Immunol. 1998; 10(1): 23-28.

[53] Sung HH, Chang HJ, Her CH, Song YL. Phenoloxidase activity of hemoeytes derived from Penaeus monodon and Maerobrachium rosenbergii. J. lnvertebr. Pathol. 1998; 71(1): 26-33.

[54] Suphantharika M, Khunrae P, Thanardkit P, Verduyn C. Preparation of spent brewer's yeast $\beta$ glucans with a potential application as an immunostimulant for black tiger shrimp, Penacus monodon. Bioresour.Technol. 2003; 88(1): 55-60.

[55] Bai SC, Kyeongjun L, Wilson RP. Different levels of dietary DL- $\alpha$-tocopheryl acetate affect the vitamin E status of juvenile Korean rockfish, Sebastes schlegeli. Aquaculture, 1998; 161(1): 405-414.

[56] Han HJ, Kim DH, Lee DC, Kim SM, Park SI. Pathogenicity of Edwardsiella tarda to olive flounder, Paralichthys olivaceus (Temminck \& Schlegel). J. Fish Dis. 2006; 29(10): 601-609.

[57] Asea A, Kraeft SA, Kurt-Jones EA, Stevenson MA, Calderwood SK. HSP70 stimulates cytokine production through a CD14-dependant pathway, demonstrating its dual role as a chaperone and cytokine. Nat. Med. 2000; 6(4): 435-442.

[58] Mun OZM, Cedenq R. Measurement of reactive oxygen intermediate production in haemoeytes of the penaeid shrimp Penaeus vannamei. Aquaculture, 2000; 191: 89-107.

[59] Meng XC, Wang B, Cong W, Du HW, Zhang AH, Zhang XJ. Metabolomics reveals ecological significance of secondary metabolites in Scutellaria baicalensis under drought stress. BMC Plant Biol. 2020; 10.21203/rs.3.rs-23642/v1.

[60] Song J, Zhou YZ, Pang YY, Gao L, Du GH, Qin XM. The anti-aging effect of Scutellaria 
522 Table 1

523 Primers used in qRT-PCR on mRNA of immune parameters.

524

\begin{tabular}{|c|c|c|c|}
\hline Gene & Forward primer (5'-3') & Reverse primer (5'-3') & Gene ID \\
\hline proPO & TACATGCACCAGCAAATTATCG & AGTTTGGGGAAGTAGCCGTC & HF570111.1 \\
\hline HSP70 & CTCTGCCCAAGCAAGTAT & GAATCTGTGCCTTATCCA & HG001455.1 \\
\hline $\mathrm{NF}-\kappa \mathrm{B}$ & GTGGCTCACTTACGACTC & AAGGTCCATACTCTTTGC & KR827675.1 \\
\hline Toll-R & TCTACGACCGCAACGAGC & CGGAGTGGGAGTGAACAG & JF895474.1 \\
\hline$\beta$-actin & GTGCGTGACATCAAGGAA & GTGCGTGACATCAAGGAA & AF221096.1 \\
\hline
\end{tabular}


528

529

530

531

532 


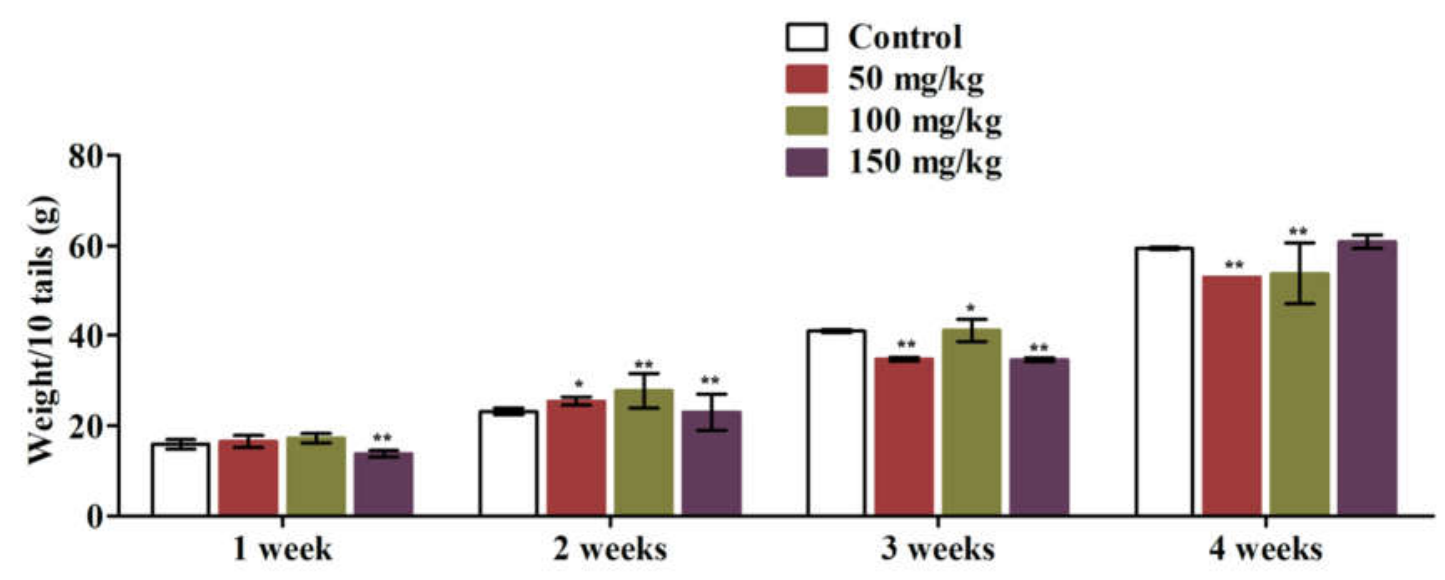

535 Fig.1 Effects of SPS on the body weight of M. rosenbergii (10 tails) for four weeks in 536 control, $50 \mathrm{mg} / \mathrm{kg}, 100 \mathrm{mg} / \mathrm{kg}$ and $150 \mathrm{mg} / \mathrm{kg}$ groups. Data presented are from three 537 independent experiments, and values represent means and standard deviations (SD).

$538 *$ indicates $\mathrm{P}<0.05$, ** indicates $\mathrm{P}<0.01$. Error bars indicate mean $\pm \mathrm{SD}, \mathrm{n}=3$. 

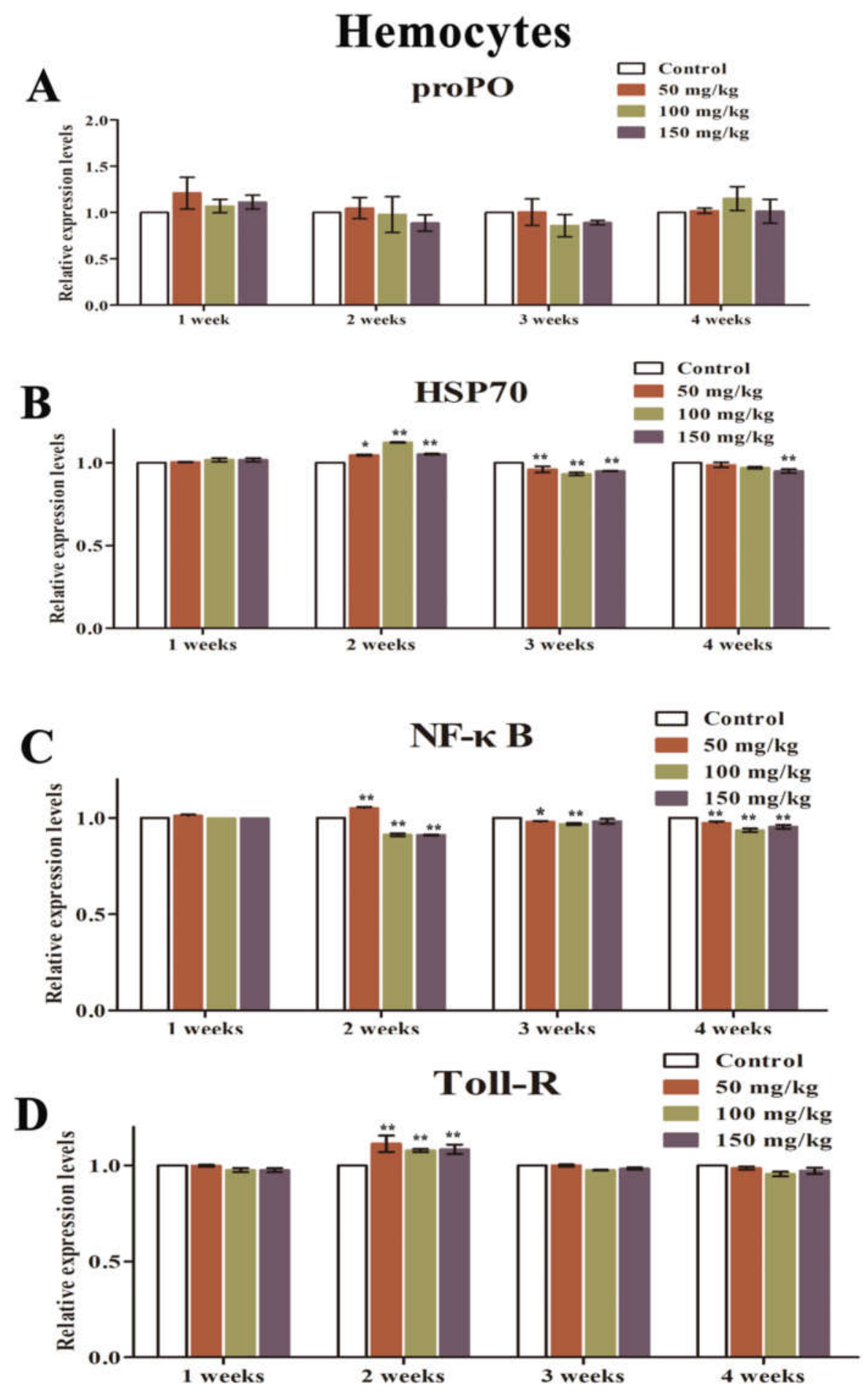

552 Fig.2 Effects of SPS on mRNA levels of immune factors in hemocytes. The mRNA 553 level of proPO (A), HSP70 (B), NF-אB (C) and Toll-R (D) from hemocytes for four 554 weeks. Data presented are from three independent experiments, and values represent 555 means and standard deviations (SD). * indicates $\mathrm{P}<0.05$, ** indicates $\mathrm{P}<0.01$. Error 556 bars indicate mean $\pm \mathrm{SD}, \mathrm{n}=3$. 

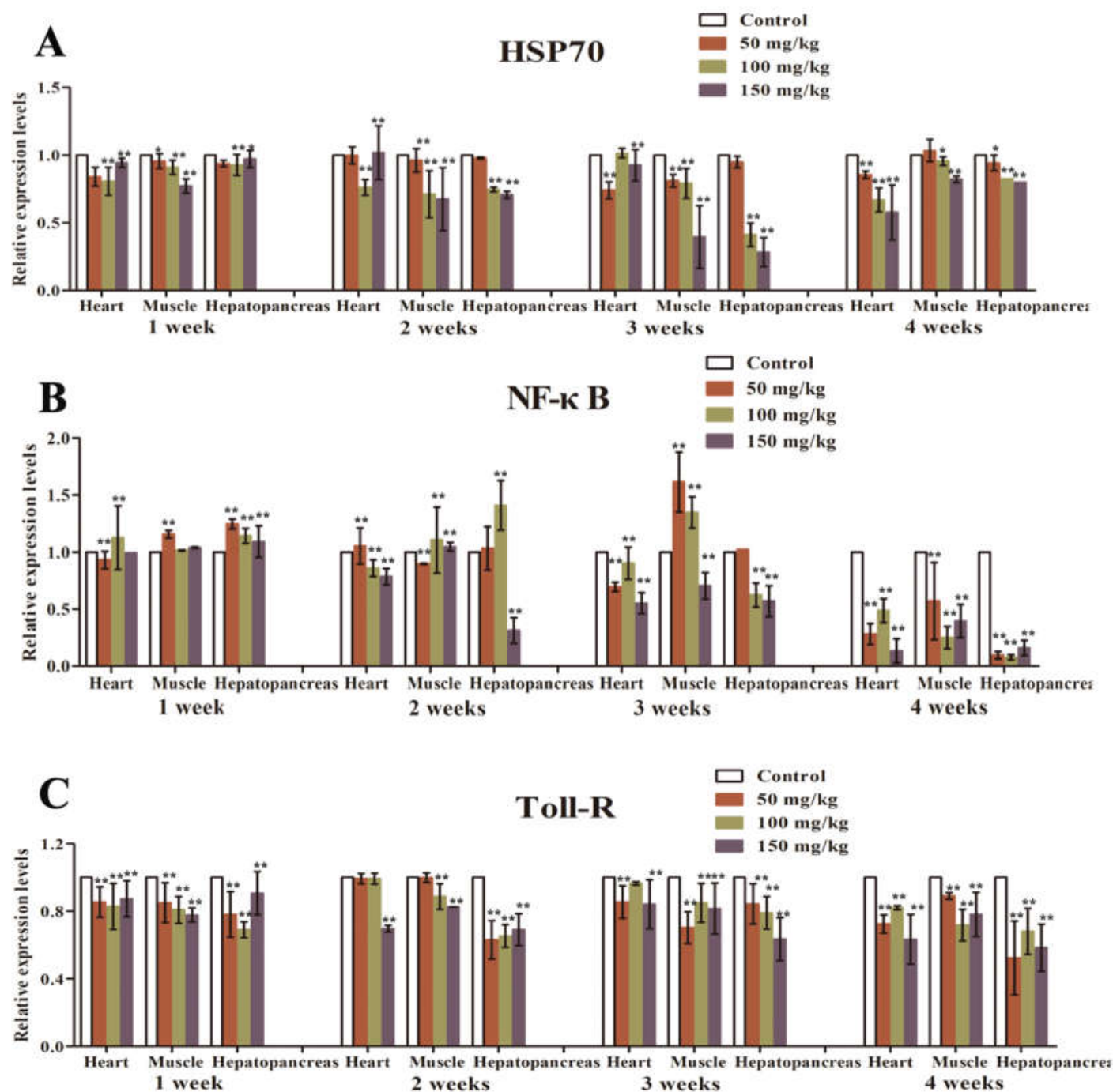

Fig. 3 Effects of SPS on mRNA levels of immune factors in tissues. The mRNA level of HSP70 (A) , NF-кB (B) and Toll-R (C) from heart, muscle and hepatopancreas for four weeks. Data presented are from three independent experiments, and values represent means and standard deviations $(\mathrm{SD}) .{ }^{*}$ indicates $\mathrm{P}<0.05, * *$ indicates $\mathrm{P}<$ 0.01. Error bars indicate mean $\pm \mathrm{SD}, \mathrm{n}=3$. 


\section{Hemocytes}
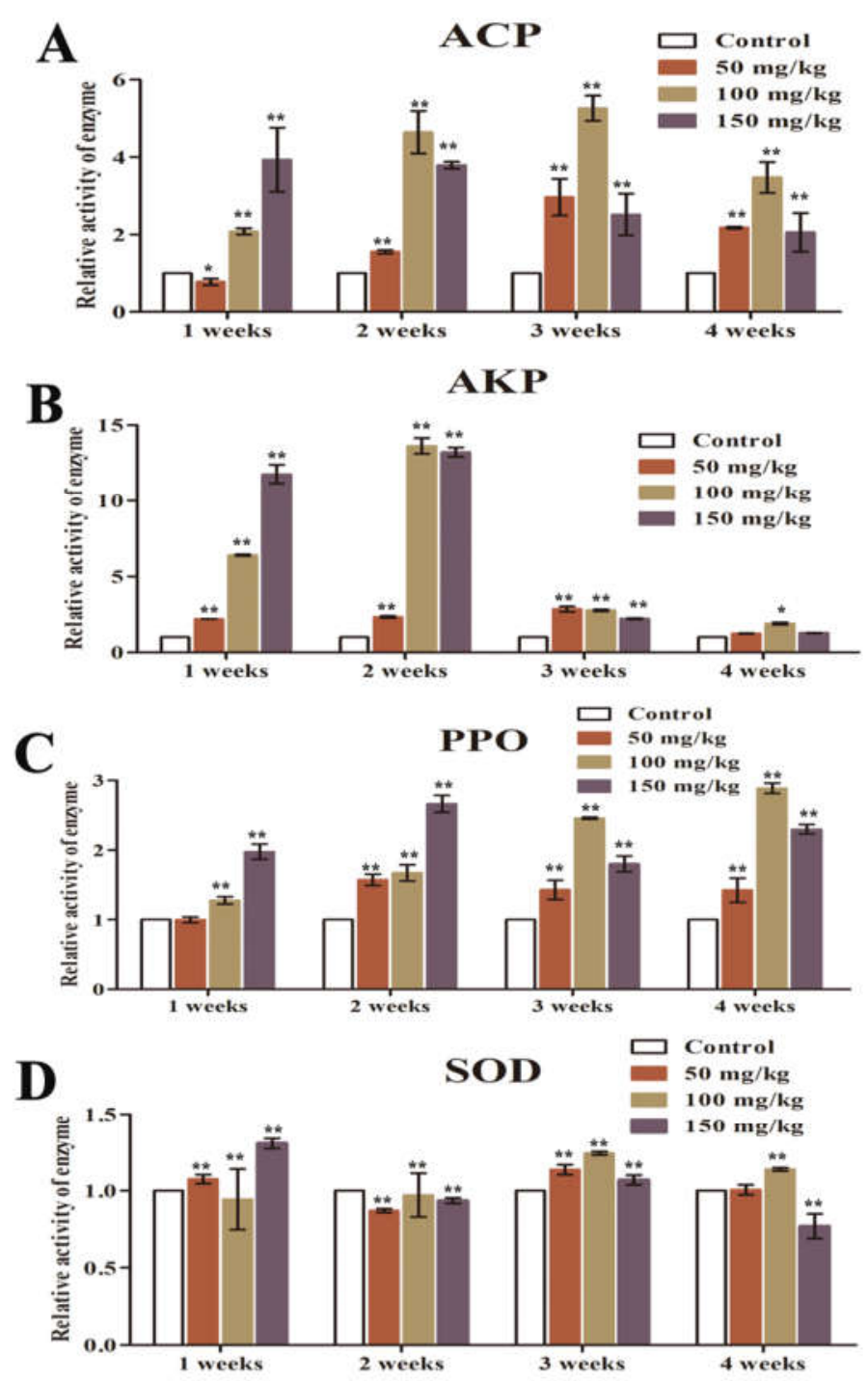

$\mathbf{E}$

CA T

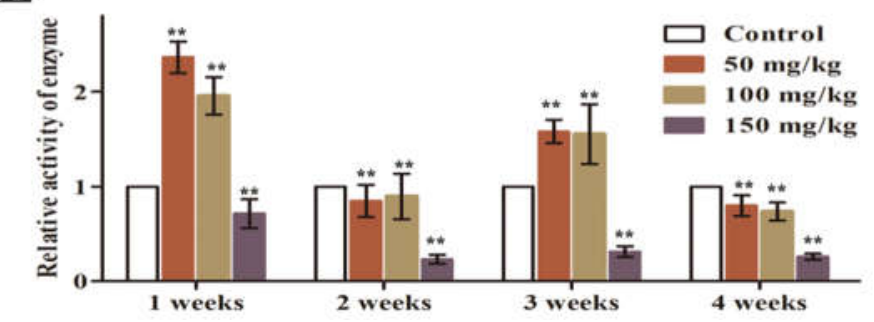

571 Fig. 4 Effect of SPS on the activities of antioxidant enzymes in M. rosenbergii. The

572 activities of ACP (A), AKP (B), PPO (C), SOD (D) and CAT (E) from hemocytes for

573 four weeks. Data presented are from three independent experiments, and values

574 represent means and standard deviations (SD). * indicates $\mathrm{P}<0.05$, ** indicates $\mathrm{P}<$

575 0.01. Error bars indicate mean $\pm \mathrm{SD}, \mathrm{n}=3$. 

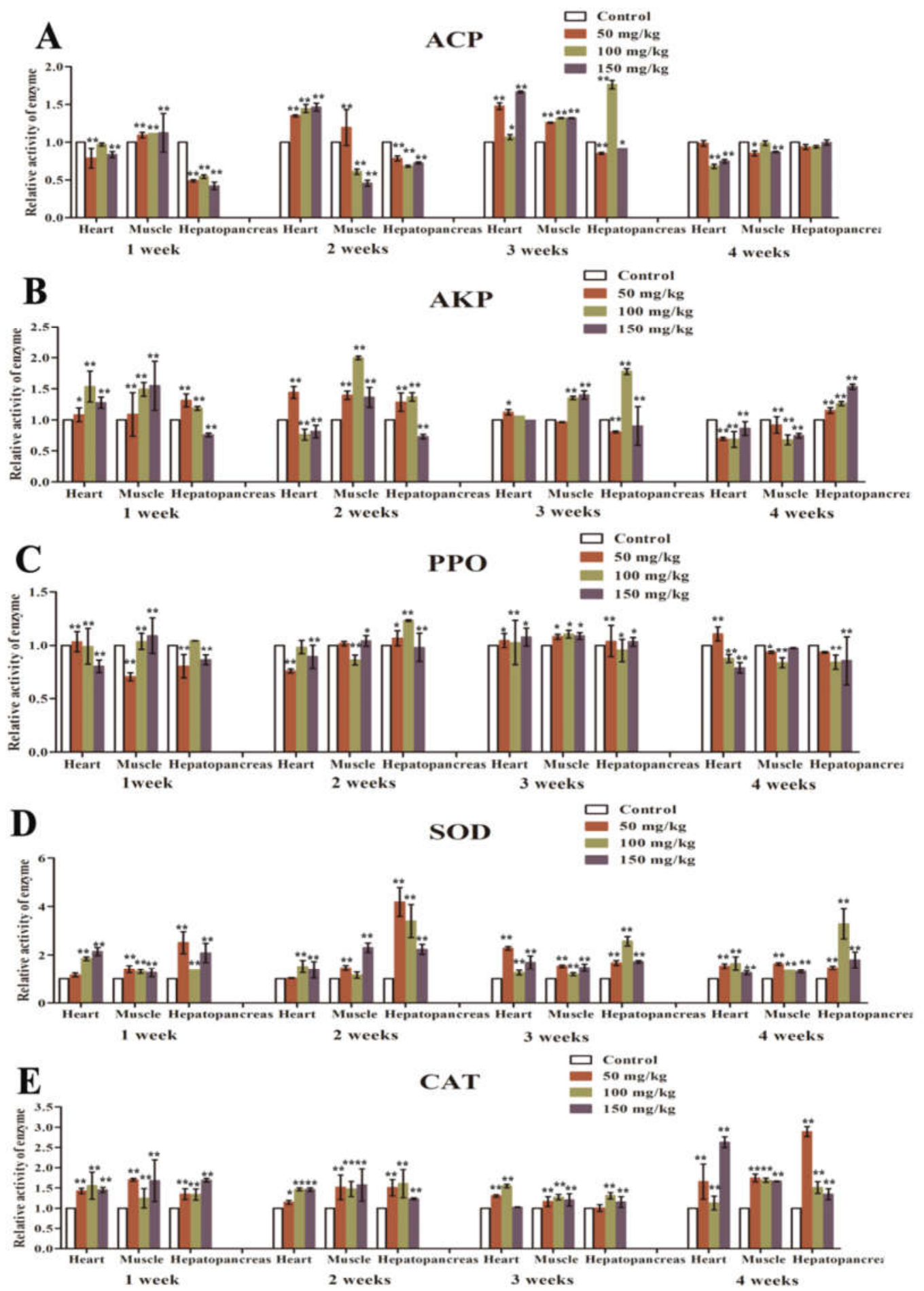

577 Fig. 5 Effect of SPS on the activities of antioxidant enzymes in M. rosenbergii. The activities of ACP (A), AKP (B), PPO (C), SOD (D) and CAT (E) from heart, muscle and hepatopancreas for four weeks. Data presented are from three independent experiments, and values represent means and standard deviations (SD). * indicates $\mathrm{P}<$ $0.05, * *$ indicates $\mathrm{P}<0.01$. Error bars indicate mean $\pm \mathrm{SD}, \mathrm{n}=3$. 


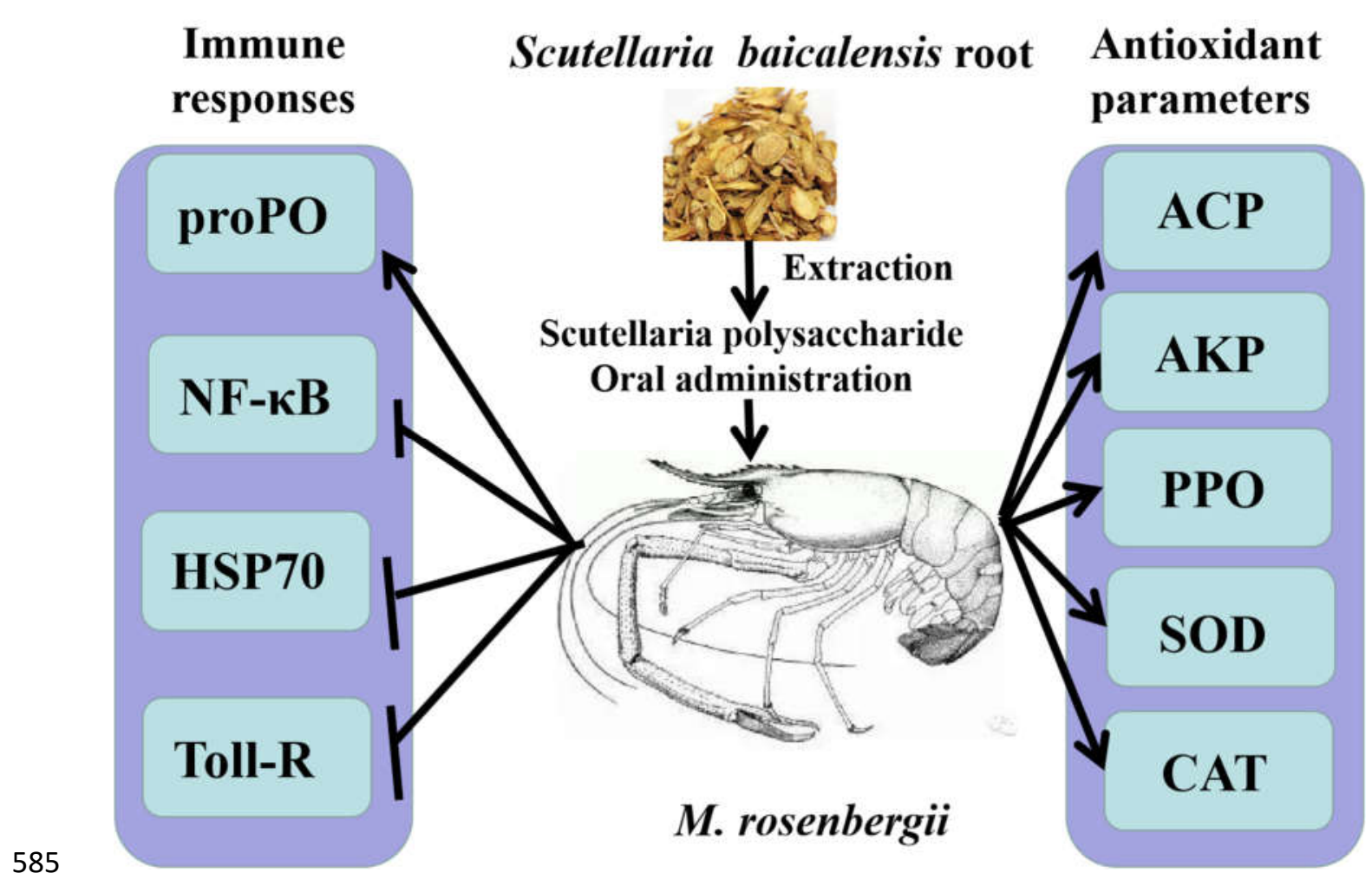

586

Fig. 6 Effect of SPS on immunity and antioxidant capacity of M. rosenbergii. The arrows show facilitation and the horizontal lines show inhibition. 


\section{Figures}

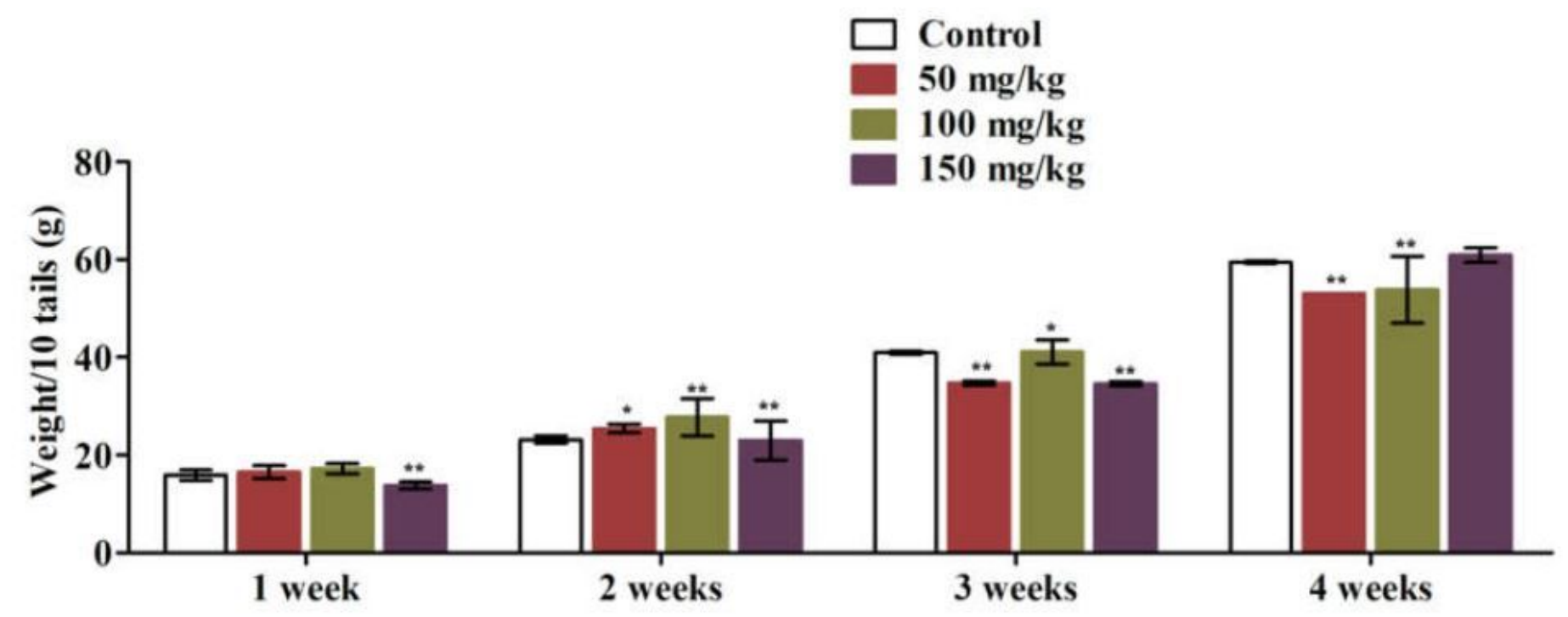

Figure 1

Effects of SPS on the body weight of M. rosenbergii (10 tails) for four weeks in control, $50 \mathrm{mg} / \mathrm{kg}, 100$ $\mathrm{mg} / \mathrm{kg}$ and $150 \mathrm{mg} / \mathrm{kg}$ groups. Data presented are from three independent experiments, and values represent means and standard deviations (SD). * indicates $P<0.05$, ** indicates $P<0.01$. Error bars indicate mean $\pm S D, n=3$. 


\section{Hemocytes}
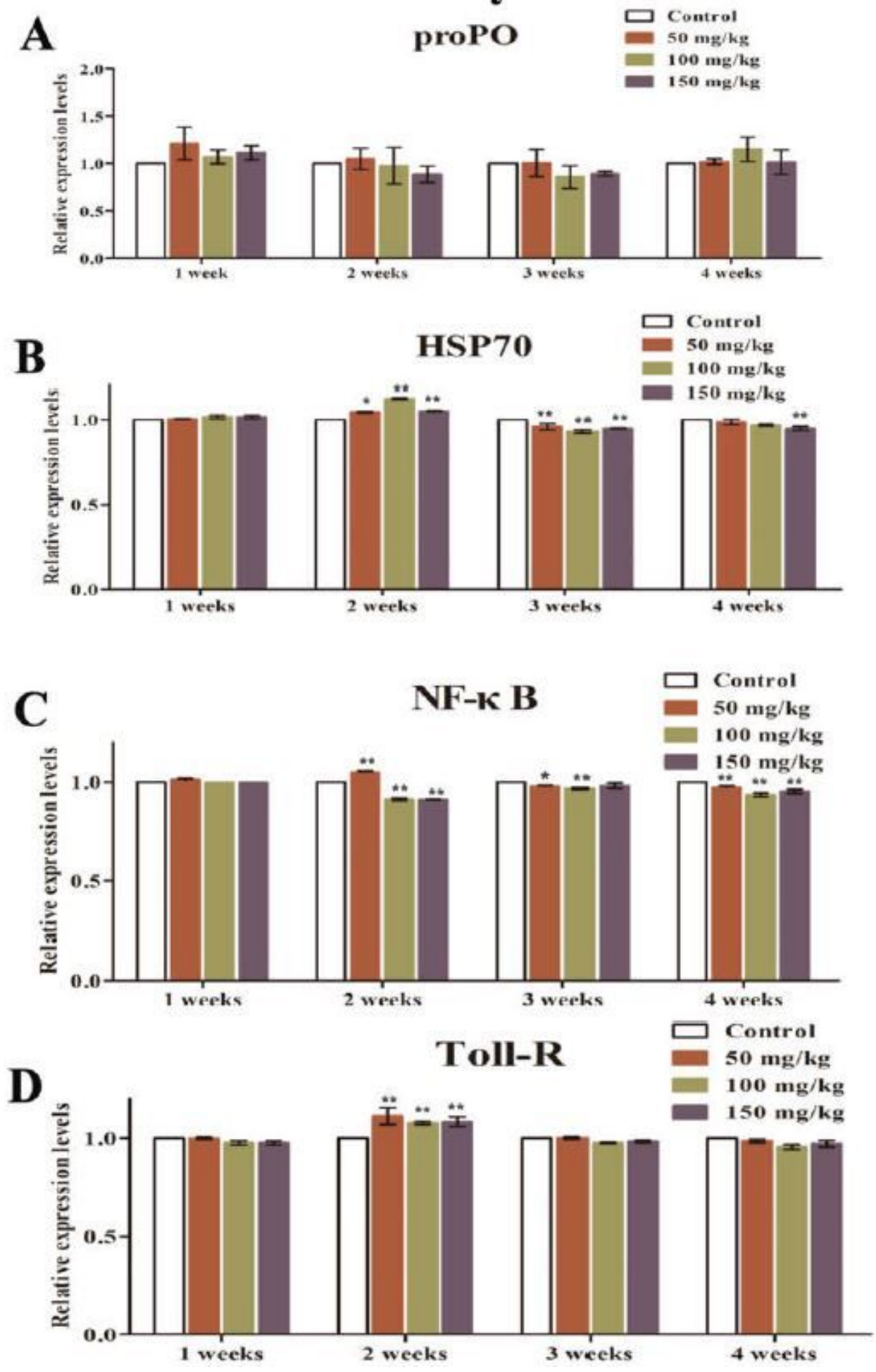

Figure 2

Effects of SPS on mRNA levels of immune factors in hemocytes. The mRNA level of proPO (A), HSP70

(B) , NF-KB (C) and Toll-R (D) from hemocytes for four weeks. Data presented are from three independent experiments, and values represent means and standard deviations (SD). * indicates $P<0.05$, ** indicates $P<0.01$. Error bars indicate mean $\pm S D, n=3$. 

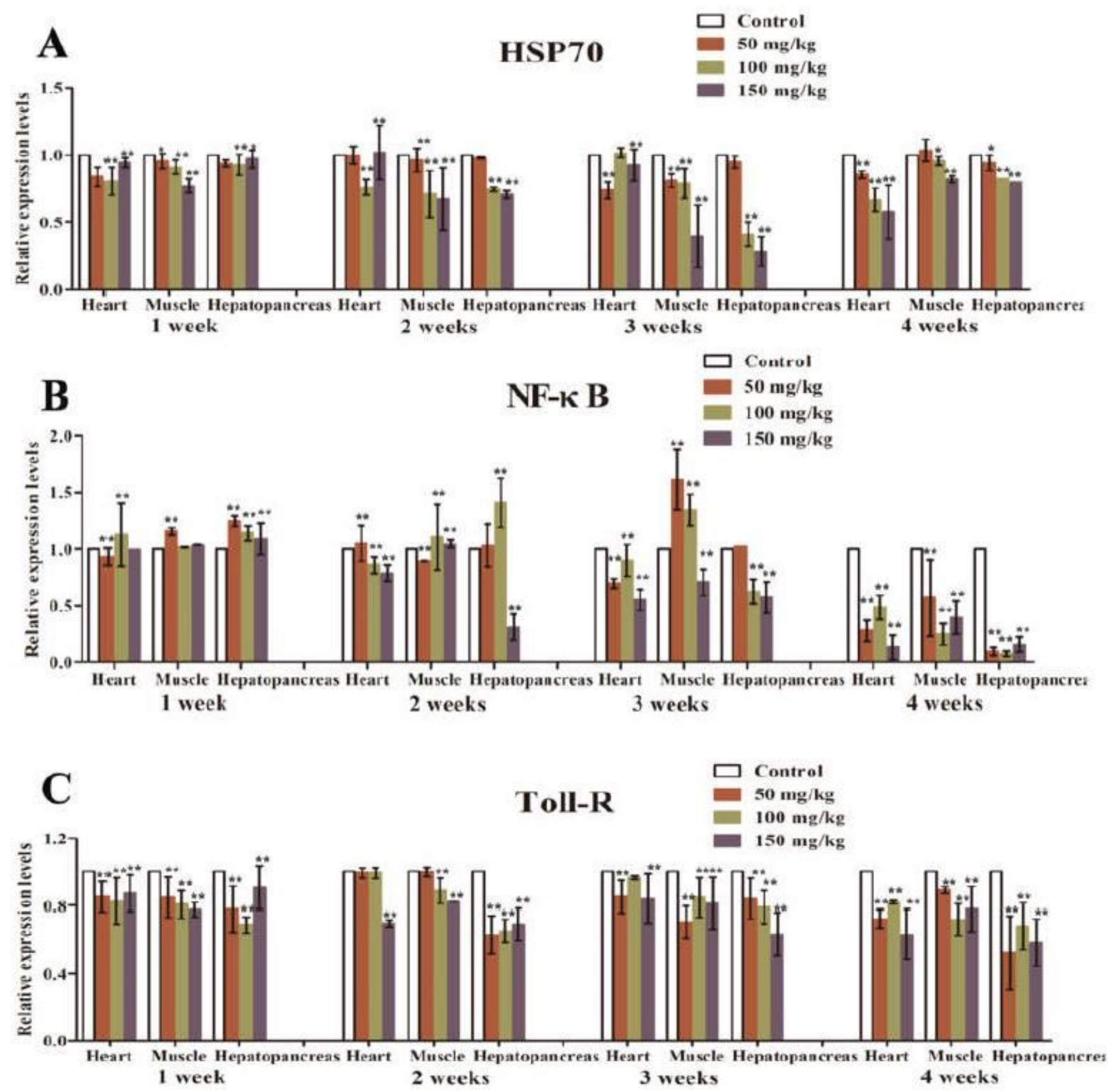

Figure 3

Effects of SPS on mRNA levels of immune factors in tissues. The mRNA level of HSP70 (A) , NF-KB (B) and Toll-R (C) from heart, muscle and hepatopancreas for four weeks. Data presented are from three independent experiments, and values represent means and standard deviations (SD). * indicates $\mathrm{P}<0.05$, ** indicates $P<0.01$. Error bars indicate mean $\pm S D, n=3$. 


\section{Hemocytes}
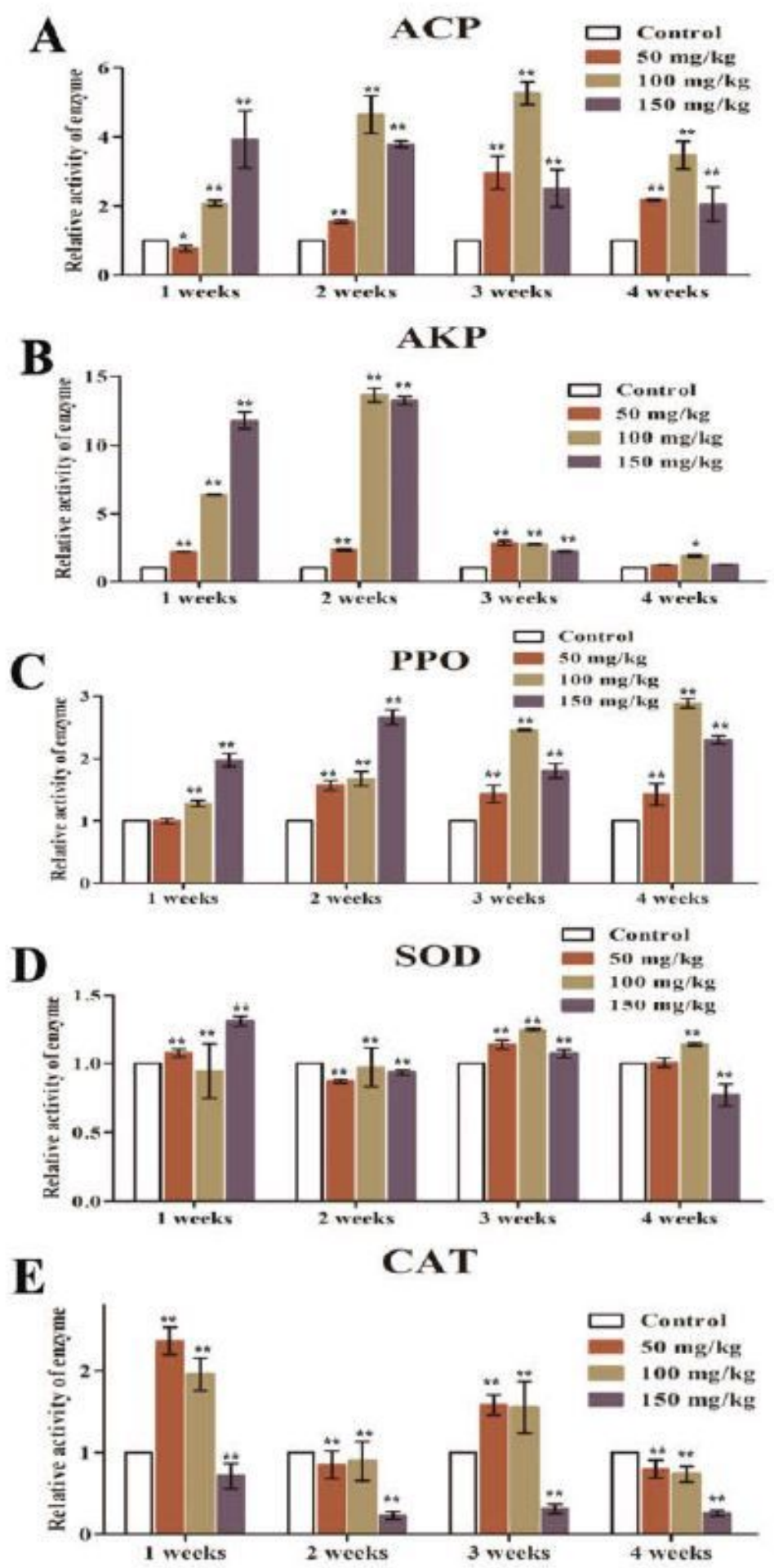

\section{Figure 4}

Effect of SPS on the activities of antioxidant enzymes in M. rosenbergii. The activities of ACP (A), AKP (B), PPO (C), SOD (D) and CAT (E) from hemocytes for four weeks. Data presented are from three independent experiments, and values represent means and standard deviations (SD). * indicates $\mathrm{P}<0.05$, ** indicates $P<0.01$. Error bars indicate mean $\pm S D, n=3$. 

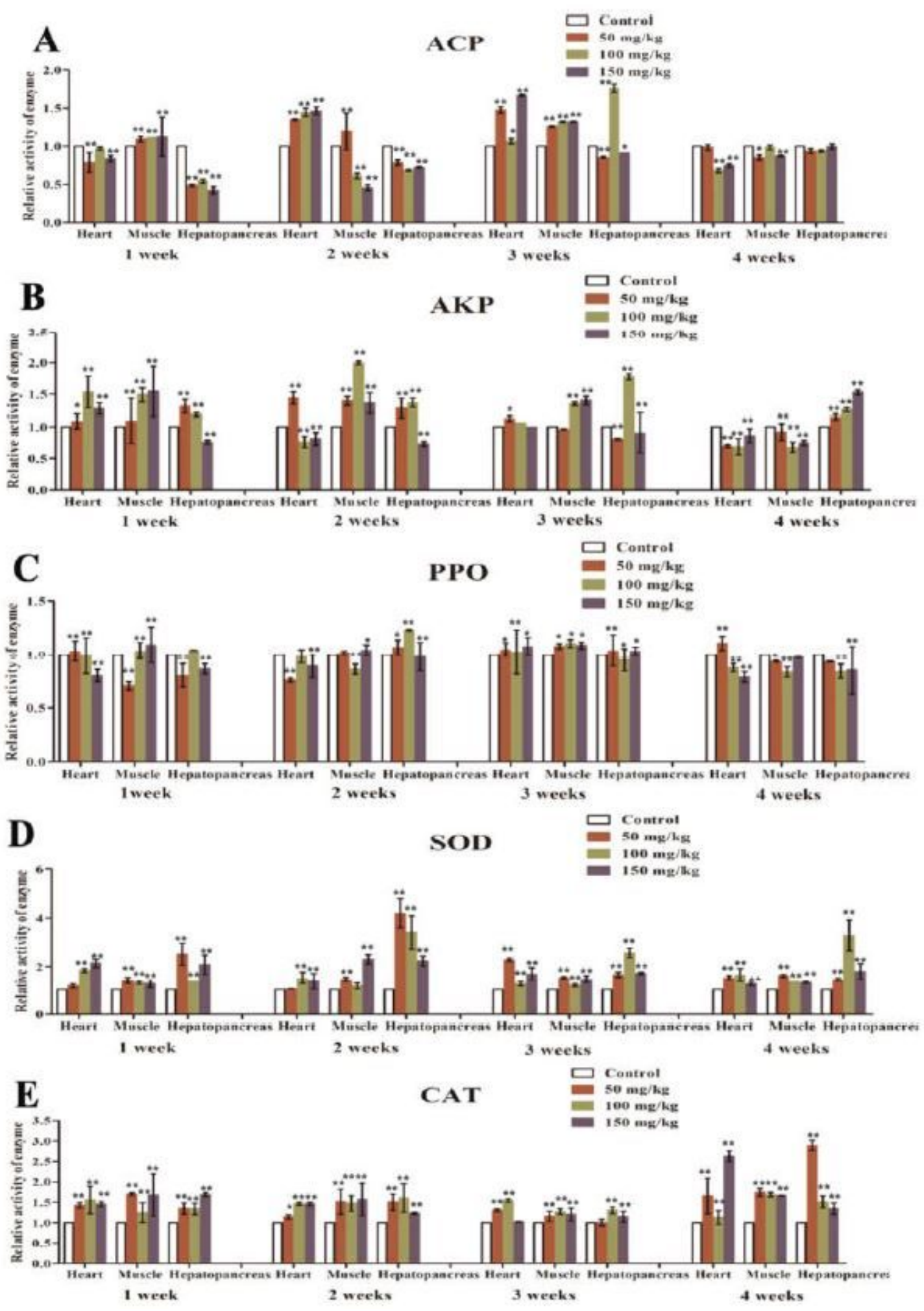

Figure 5

Effect of SPS on the activities of antioxidant enzymes in M. rosenbergii. The activities of ACP (A), AKP (B), PPO (C), SOD (D) and CAT (E) from heart, muscle and hepatopancreas for four weeks. Data presented are from three independent experiments, and values represent means and standard deviations (SD). * indicates $P<0.05$, ** indicates $P<0.01$. Error bars indicate mean $\pm S D, n=3$. 


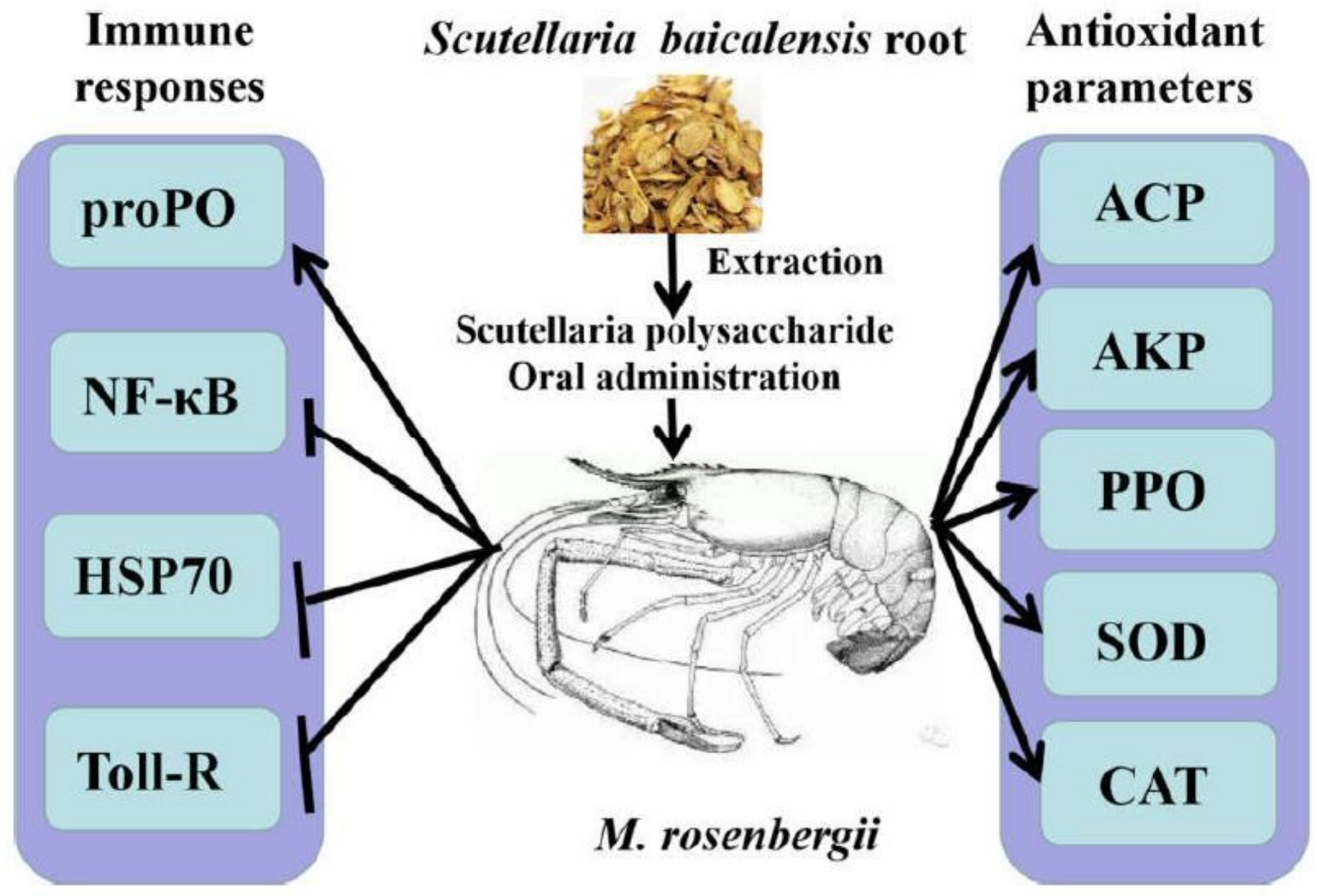

Figure 6

Effect of SPS on immunity and antioxidant capacity of M. rosenbergii. The arrows show facilitation and the horizontal lines show inhibition. 